\title{
DETERMINATION OF BIO-VARIATION AMONG DIFFERENT MULBERRY SPECIES GROWN IN TOKAT REGION OF TURKEY BY MOLECULAR MARKERS
}

\author{
CEKIC, C. ${ }^{{ }^{*}}-$ OZMEN, Z. S. ${ }^{2}$ \\ ${ }^{1}$ Department of Horticulture, Faculty of Agriculture, Gaziosmanpaşa University, Tokat, Turkey \\ ${ }^{2}$ Middle Black Sea Transitional Zone Agricultural Research Institute, Tokat, Turkey \\ *Corresponding author \\ e-mail: cetin.cekic@gop.edu.tr \\ (Received $29^{\text {th }}$ May 2018; accepted $11^{\text {th }}$ Jul 2018)
}

\begin{abstract}
The aim of this research is to determinate diversity of mulberries grown in North Anatolia between or within species by ISSR markers. In the study, 38 different mulberry genotypes collected from Tokat region in Turkey were used. ISSR-PCR analyses were carried out on the DNA of genotypes isolated using mini-CTAB extraction method. The levels of polymorphism between genotypes were determined using the UBC-ISSR primers. A total of 96 bands were obtained from 15 UBC ISSR primers. Out of 96 bands, 80 bands were polymorphic. The number of bands obtained per primer ranged between 4 and 11, the average number of bands were determined as 6.4. The average number of polymorphic bands per primer was 5.33. Similarities and differences between genotypes have been studied at the molecular level. The data used for statistical analysis were obtained by the evaluation of ISSR bands. Similarity coefficient and UPGMA dendrogram were built using the Basic Coordinates Analysis. According to the dendrogram, the genotypes have been divided in two main groups, one small and one large group. While the small group was only comprised of black mulberry genotypes, the large group included white mulberry, weeping mulberry and wild white mulberry genotypes. Different mulberry species have been divided into different subgroups within the large group. The polimorfism level within the species was lowest in black mulberry genotypes, and this was followed by weeping mulberry, white mulberry and wild white mulberry genotypes, respectively.
\end{abstract}

Keywords: similarity, diversity, dendrogram, North Anatolia, mulberry

\section{Introduction}

Mulberry is a perennial fruit species belonging to the genus Morus of the family Moraceae (Datta, 2002; Anonymous, 2006). Morus, a genus of flowering plants in the family Moraceae, deciduous trees commonly known as mulberries, grow wild and under cultivation in many temperate world regions. The origin of mulberry is Asia (Awasthi et al., 2004). Over 150 species names have been published, and although differing sources may cite different selections of accepted names, only 10-16 are generally cited as being accepted by the vast majority of botanical authorities. Morus classification is even further complicated by widespread hybridisation, wherein the hybrids are fertile. Mulberry trees are either dioecious or monoecious and sometimes will transform from one sex to another. The flowers are held on short, green, pendulous, nondescript catkins that emerge in the axils of the current season's growth and on spurs on older wood. They are wind pollinated and some cultivars will set fruit without any pollination (Anonymous, 2009).

Black, red, and white mulberry are widespread in southern Europe, the Middle East, northern Africa and Indian subcontinent, where the tree and the fruit have names under regional dialects. The most important mulberry species are Morus alba (white 
mulberry), Morus australis (Chinese mulberry), Morus indica (Indian mulberry), Morus microphylla (Texas mulberry), Morus nigra (Black mulberry), Morus rubra (Redpurple mulberry) and Morus serrata (Himalian mulberry) (Tutin, 1996; Vijayan et al., 2004). It is sometimes difficult to distinguish mulberry species morphologically and pomologically from each other, especially the fruits of Morus nigra, Morus rubra and Morus pendula species, those with black fruits. In fact, cheaper black fruits are sometimes sold in markets instead of Morus nigra fruits in high prices (Günes and Cekic, 2004; Erdogan and Pirlak, 2005). Therefore, determining the difference in the species and between species at the molecular level is important in terms of consumers as well as in terms of scientific literature.

The mulberry plants are deciduous and are produced for their fruit and leaves in all parts of Turkey (Anonymous, 2009). The species M. alba, M. nigra and M. rubra are common in Turkey (Ercisli, 2004; Ercisli and Orhan, 2007; Özgen et al., 2009). The main mulberry production areas of Turkey are Black Sea Region and Eastern and Central Anatolian Regions. Turkey has very old mulberry cultivation, and mulberries are one of the main fruits grown by Turkish farmers. The four mulberry species (Morus alba, Morus nigra, Morus rubra, Morus laevigata) can be seen in different agroclimatic regions in Turkey. There is no registered mulberry cultivar in Turkey but each region has its own local genotypes which are propagated by budding or grafting over many years (Ercisli and Orhan, 2007).

Tokat Province of Turkey, at the mid Black Sea region of Anatolia, has a hotsummer Mediterranean climate with considerable maritime and continental influences. Most parts of province are suitable for mulberry production, and some species of mulberry spread over the province. Although there is no intensive mulberry production by producers, one or two mulberry trees can be seen almost in every orchard, especially near by homes.

The aim of this research is to determinate diversity of mulberries grown in North Anatolia (Tokat Province) between or within species by ISSR markers.

\section{Material and methods}

\section{Plant material}

For research purposes, a total of 38 different mulberry genotypes from Tokat region in Turkey were used (Table 1; Fig. 1). Out of total number 15 belongs to black (Morus nigra), 13 to white (Morus alba), 5 to pendulous (Morus pendula), 2 to everbearing mulberry (Morus alba) and 3 to wild mulberry (Morus alba).

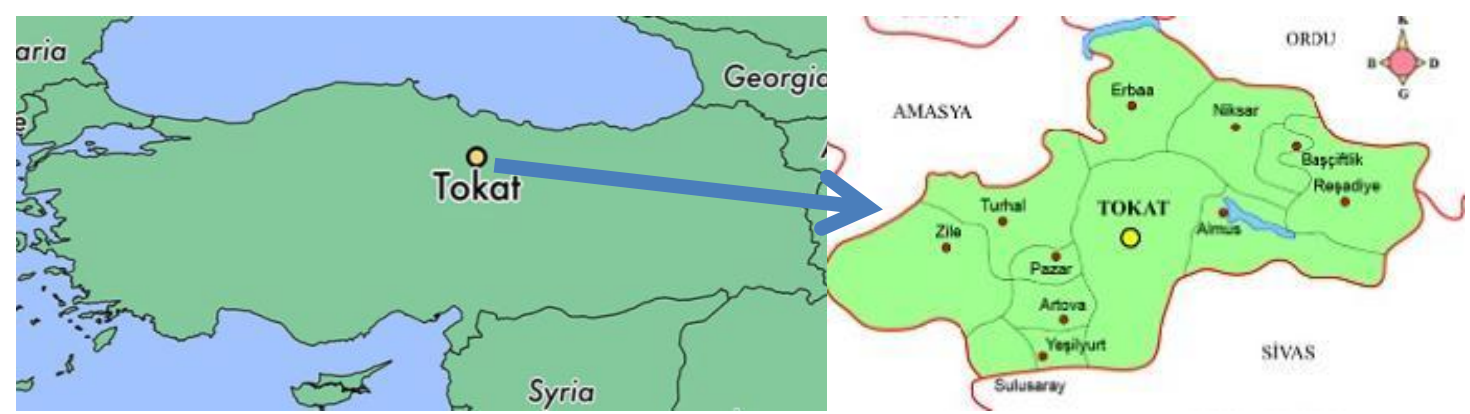

Figure 1. The localization of Tokat province in Turkey, where the samples were collected 
Table 1. The latitudes, longitudes and elevations of the samples taken

\begin{tabular}{|c|c|c|c|c|}
\hline & Sample code & Elevation (m) & Latitude & Longitude \\
\hline 1 & $\mathrm{~K} 1$ & $608 \mathrm{~m}$ & $40^{\circ} 20.014 \mathrm{~N}$ & $36^{\circ} 31.065 \mathrm{E}$ \\
\hline 2 & K2 & $730 \mathrm{~m}$ & $40^{\circ} 18.863 \mathrm{~N}$ & $36^{\circ} 32.191 \mathrm{E}$ \\
\hline 3 & K3 & $679 \mathrm{~m}$ & $40^{\circ} 18.964 \mathrm{~N}$ & $36^{\circ} 32.925 \mathrm{E}$ \\
\hline 4 & K4 & $700 \mathrm{~m}$ & $40^{\circ} 18.307 \mathrm{~N}$ & $36^{\circ} 33.092 \mathrm{E}$ \\
\hline 5 & K5 & $671 \mathrm{~m}$ & $40^{\circ} 17.390 \mathrm{~N}$ & $36^{\circ} 33.017 \mathrm{E}$ \\
\hline 6 & K6 & $689 \mathrm{~m}$ & $40^{\circ} 17.860 \mathrm{~N}$ & $36^{\circ} 33.454 \mathrm{E}$ \\
\hline 7 & K7 & $677 \mathrm{~m}$ & $40^{\circ} 18.229 \mathrm{~N}$ & $36^{\circ} 33.682 \mathrm{E}$ \\
\hline 8 & K8 & $589 \mathrm{~m}$ & $40^{\circ} 20.551 \mathrm{~N}$ & $36^{\circ} 31.812 \mathrm{E}$ \\
\hline 9 & K9 & $667 \mathrm{~m}$ & $40^{\circ} 21.387 \mathrm{~N}$ & $36^{\circ} 31.565 \mathrm{E}$ \\
\hline 10 & K10 & $658 \mathrm{~m}$ & $40^{\circ} 21.336 \mathrm{~N}$ & $36^{\circ} 31.582 \mathrm{E}$ \\
\hline 11 & K11 & $613 \mathrm{~m}$ & $40^{\circ} 20.356 \mathrm{~N}$ & $36^{\circ} 33.272 \mathrm{E}$ \\
\hline 12 & K12 & $615 \mathrm{~m}$ & $40^{\circ} 20.317 \mathrm{~N}$ & $36^{\circ} 33.321 \mathrm{E}$ \\
\hline 13 & K13 & $649 \mathrm{~m}$ & $40^{\circ} 20.497 \mathrm{~N}$ & $36^{\circ} 34.120 \mathrm{E}$ \\
\hline 14 & K14 & $2211 \mathrm{~m}$ & $40^{\circ} 17.269 \mathrm{~N}$ & $36^{\circ} 33.065 \mathrm{E}$ \\
\hline 15 & K15 & $2214 \mathrm{~m}$ & $40^{\circ} 17.266 \mathrm{~N}$ & $36^{\circ} 33.064 \mathrm{E}$ \\
\hline 16 & $\mathrm{~B} 1$ & $730 \mathrm{~m}$ & $40^{\circ} 18.804 \mathrm{~N}$ & $36^{\circ} 32.169 \mathrm{E}$ \\
\hline 17 & B2 & $676 \mathrm{~m}$ & $40^{\circ} 18.506 \mathrm{~N}$ & $36^{\circ} 32.925 \mathrm{E}$ \\
\hline 18 & B3 & $659 \mathrm{~m}$ & $40^{\circ} 18.024 \mathrm{~N}$ & $36^{\circ} 33.086 \mathrm{E}$ \\
\hline 19 & B4 & $740 \mathrm{~m}$ & $40^{\circ} 17.423 \mathrm{~N}$ & $36^{\circ} 33.136 \mathrm{E}$ \\
\hline 20 & B5 & $589 \mathrm{~m}$ & $40^{\circ} 20.551 \mathrm{~N}$ & $36^{\circ} 31.812 \mathrm{E}$ \\
\hline 21 & B6 & $617 \mathrm{~m}$ & $40^{\circ} 20.442 \mathrm{~N}$ & $36^{\circ} 32.796 \mathrm{E}$ \\
\hline 22 & B7 & $615 \mathrm{~m}$ & $40^{\circ} 20.391 \mathrm{~N}$ & $36^{\circ} 33.175 \mathrm{E}$ \\
\hline 23 & B8 & $611 \mathrm{~m}$ & $40^{\circ} 20.225 \mathrm{~N}$ & $36^{\circ} 33.341 \mathrm{E}$ \\
\hline 24 & B9 & $618 \mathrm{~m}$ & $40^{\circ} 20.219 \mathrm{~N}$ & $36^{\circ} 34.123 \mathrm{E}$ \\
\hline 25 & B10 & $2214 \mathrm{~m}$ & $40^{\circ} 17.266 \mathrm{~N}$ & $36^{\circ} 33.063 \mathrm{E}$ \\
\hline 26 & B11 & $2185 \mathrm{~m}$ & $40^{\circ} 17.293 \mathrm{~N}$ & $36^{\circ} 33.016 \mathrm{E}$ \\
\hline 27 & B12 & $2211 \mathrm{~m}$ & $40^{\circ} 17.269 \mathrm{~N}$ & $36^{\circ} 33.065 \mathrm{E}$ \\
\hline 28 & B13 & $2270 \mathrm{~m}$ & $40^{\circ} 17.504 \mathrm{~N}$ & $36^{\circ} 33.539 \mathrm{E}$ \\
\hline 29 & $\mathrm{~S} 1$ & $2270 \mathrm{~m}$ & $40^{\circ} 17.504 \mathrm{~N}$ & $36^{\circ} 33.539 \mathrm{E}$ \\
\hline 30 & S2 & $589 \mathrm{~m}$ & $40^{\circ} 18.804 \mathrm{~N}$ & $36^{\circ} 32.169 \mathrm{E}$ \\
\hline 31 & S3 & $658 \mathrm{~m}$ & $40^{\circ} 18.506 \mathrm{~N}$ & $36^{\circ} 32.925 \mathrm{E}$ \\
\hline 32 & S4 & $619 \mathrm{~m}$ & $40^{\circ} 18.024 \mathrm{~N}$ & $36^{\circ} 33.086 \mathrm{E}$ \\
\hline 33 & S5 & $626 \mathrm{~m}$ & $40^{\circ} 17.423 \mathrm{~N}$ & $36^{\circ} 33.136 \mathrm{E}$ \\
\hline 34 & Y1 & $679 \mathrm{~m}$ & $40^{\circ} 18.964 \mathrm{~N}$ & $36^{\circ} 32.925 \mathrm{E}$ \\
\hline 35 & Y2 & $667 \mathrm{~m}$ & $40^{\circ} 21.387 \mathrm{~N}$ & $36^{\circ} 31.565 \mathrm{E}$ \\
\hline 36 & YB1 & $659 \mathrm{~m}$ & $40^{\circ} 18.024 \mathrm{~N}$ & $36^{\circ} 33.086 \mathrm{E}$ \\
\hline 37 & YB2 & $619 \mathrm{~m}$ & $40^{\circ} 20.456 \mathrm{~N}$ & $36^{\circ} 32.363 \mathrm{E}$ \\
\hline 38 & YB3 & $618 \mathrm{~m}$ & $40^{\circ} 18.024 \mathrm{~N}$ & $36^{\circ} 33.086 \mathrm{E}$ \\
\hline
\end{tabular}

\section{DNA extraction}

Total genomic DNA was extracted according to the CTAB method (Doyle and Doyle, 1987). DNA sample concentration was determined using a fluorometer employing a Hoechst dye (Hoefer Inc., San Francisco, CA, USA), and the DNA 
samples were diluted to a final concentration of $10 \mathrm{ng} / \mu \mathrm{l}$ with $1 \times \mathrm{TE}$ buffer and stored at $-20{ }^{\circ} \mathrm{C}$ prior to polymerase chain reaction (PCR) amplification.

\section{ISSR amplification}

15 primers that produced clear and reproducible fragments were selected out of a hundred UBC primers, which were previously tested for further analyses (Table 2). ISSR amplification was performed in a $20 \mu \mathrm{l}$ volume containing 20 ng genome DNA, $1 \times$ Taq buffer, $2.0 \mathrm{mM} \mathrm{MgCl}, 0.2 \mathrm{mM}$ dNTPs, $0.75 \mu \mathrm{M}$ primer, 0.5 units of Taq DNA polymerase. The amplification reaction consisted of an initial denaturation step at $94{ }^{\circ} \mathrm{C}$ for $5 \mathrm{~min}$, followed by 45 cycles of $45 \mathrm{~s}$ at $94{ }^{\circ} \mathrm{C}$, annealing at $50-56{ }^{\circ} \mathrm{C}$ for $45 \mathrm{~s}$, extension at $72{ }^{\circ} \mathrm{C}$ for $90 \mathrm{~s}$, and ended with extension at $72{ }^{\circ} \mathrm{C}$ for $7 \mathrm{~min}$. The amplified products were resolved electrophoretically on $2.0 \%$ agarose gels run at $100 \mathrm{~V}$ in $1.0 \times \mathrm{TBE}$ buffer, visualized by staining with ethidium bromide $(0.5 \mu \mathrm{g} / \mathrm{ml})$, and photographed under ultraviolet light (Charters et al., 1996; Rafalski et al., 1996; Cekic et al., 2001) The amplifications were repeated twice and only clear repetitive bands were used in data analysis, and molecular weights were estimated using a 100 bp DNA marker (Vivantis).

Table 2. Band number, polymorphic band number and polymorphic band ratio (\%) in mulberry genotypes

\begin{tabular}{c|c|c|c|c|c}
\hline & $\begin{array}{c}\text { ISSR primer } \\
\text { code }\end{array}$ & Primer sequence and anchors & $\begin{array}{c}\text { Band } \\
\text { number }\end{array}$ & $\begin{array}{c}\text { Polymorphic } \\
\text { band number }\end{array}$ & $\begin{array}{c}\text { Polymorphic } \\
\text { band ratio (\%) }\end{array}$ \\
\hline 1 & 807 & AGAGAGAGAGAGAGAGT & 11 & 9 & 81.81 \\
2 & 808 & AGAGAGAGAGAGAGAGC & 5 & 5 & 100.00 \\
3 & 810 & GAGAGAGAGAGAGAGAT & 8 & 6 & 75.00 \\
4 & 811 & GAGAGAGAGAGAGAGAC & 7 & 6 & 85.71 \\
5 & 826 & ACACACACACACACACC & 6 & 6 & 100.00 \\
6 & 835 & AGAGAGAGAGAGAGAGYC & 7 & 6 & 85.71 \\
7 & 841 & GAGAGAGAGAGAGAGAYC & 6 & 4 & 66.67 \\
8 & 842 & GAGAGAGAGAGAGAGAYG & 10 & 9 & 90.00 \\
9 & 844 & CTCTCTCTCTCTCTCTRC & 4 & 3 & 75.00 \\
10 & 856 & ACACACACACACACACYA & 4 & 3 & 75.00 \\
11 & 881 & GGGTGGGTGGGTGGGT & 5 & 4 & 80.00 \\
12 & 888 & BDBCACACACACACACA & 7 & 6 & 85.71 \\
13 & 889 & DBDACACACACACACAC & 4 & 3 & 75.00 \\
14 & 890 & VHVGTGTGTGTGTGTGT & 7 & 6 & 85.71 \\
15 & 891 & HVHTGTGTGTGTGTGTG & 5 & 4 & 80.00 \\
\hline \multicolumn{7}{r|}{ Average } & 6.4 & 5.33 & 82.76 \\
\hline \multicolumn{7}{r}{ Total } \\
\hline
\end{tabular}

\section{Data analysis}

The amplified fragments were scored for band presence (1) or absence (0) with all the accessions studied. Similarities and differences between genotypes have been studied at the molecular level. The data used for statistical analysis were obtained by the 
evaluation of ISSR bands. Similarity coefficient and UPGMA dendrogram were built using the Basic Coordinates Analysis (Rolf, 1992).

\section{Results and discussion}

On the basis of the number, intensity and reproducibility of ISSR bands 15 primers were selected out of a hundred UBC primers, which were previously tested (Cekic et al., 2001). Bands with the same mobility were treated as identical fragments. Weak bands with negligible intensity and smear bands were both excluded from final analysis. Each primer was evaluated for total band number (TBN), polymorphic band number (PBN) and the ratio of polymorphism ( $\mathrm{PR}=\mathrm{PBN} / \mathrm{TBN} \mathrm{X} 100)$.

The number of scored bands varied from four to eleven with an average of 6.4 bands per primer and an average of 5.33 polymorphic bands per primer. In total, 80 bands out of 96 derived from 15 primers were polymorphic (Table 2; Fig. 2).
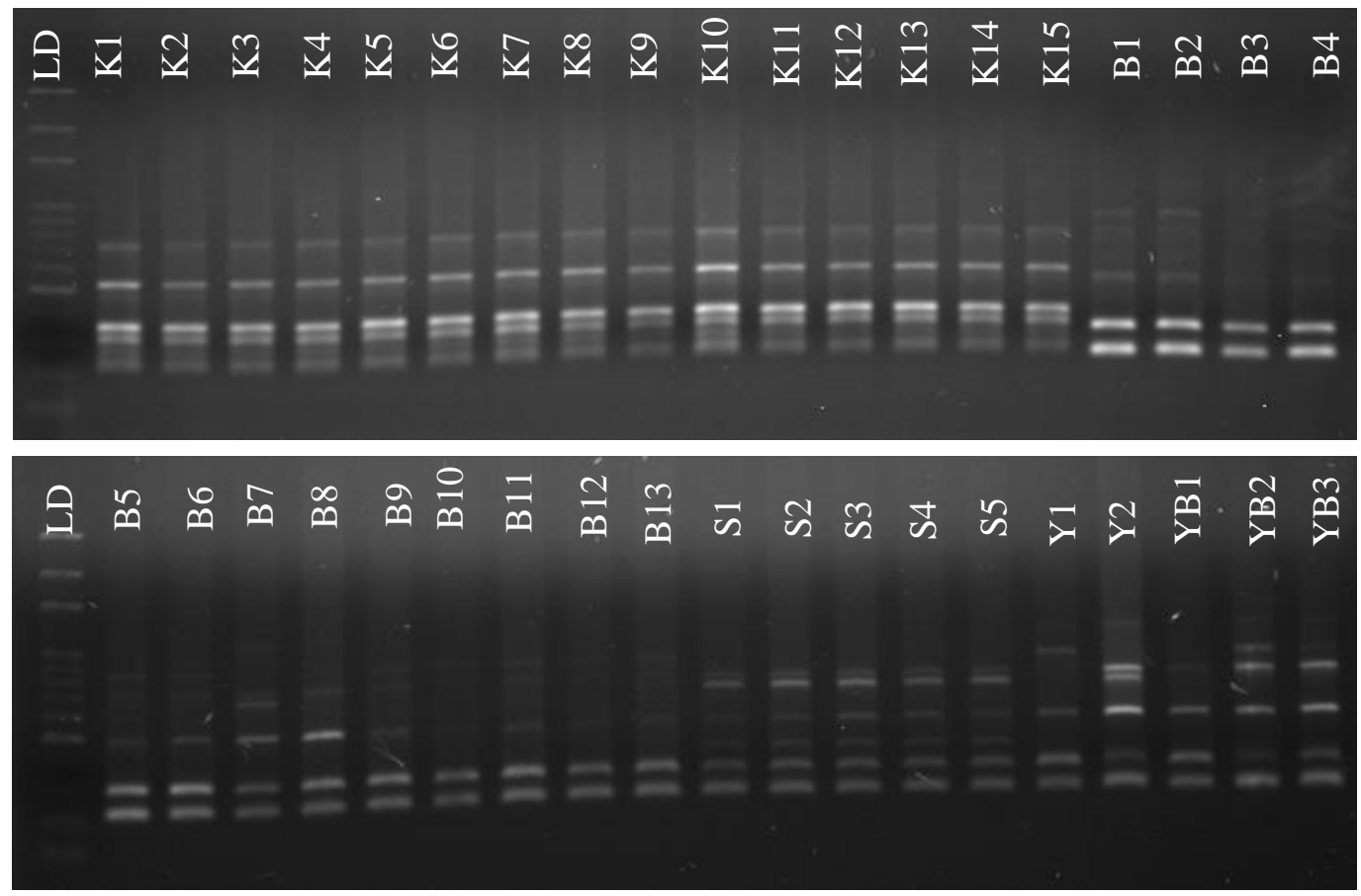

Figure 2. Agarose gel of polymorphic DNA amplification profiles of different mulberry genotypes (K: Black mulberry, B: White mulberry, S: Pendulous mulberry, Y: Everbearing mulberry (long season harvesting), YB: Wild mulberry) obtained with UBC ISSR primer 811.

(LD: 100 bp LADDER -Vivantis)

\section{Cluster analysis}

Genetic similarity among varieties was estimated using dissimilarity coefficient matrix based on ISSR bands scored. Pairwise values of dissimilarity coefficients ranged from 0.27 for genotypes with the same scored bands to 1.00 for the most similar genotypes. The dendrogram was constructed based on the similarity matrix, using UPGMA method (Rohlf, 1992). The 38 mulberry genotypes were divided into two main clusters (Fig. 3), in which black mulberry genotypes in one group and the rest of the genotypes falling under the other group. While the first major group contained only 
black mulberries, the second major cluster was further separated into subgroups. The first subgroup contained black mulberry genotypes, respectively which showed very close ISSR profile exhibited the highest genetic similarity ranges (0.95-1.00). On the other hand, the similarity of the second varied 0.75 to 0.96 , in which different mulberry species (White mulberry, Pendulous mulberry, Everbearing mulberry, Wild mulberry) separated in different clusters at various stages (Fig. 2).

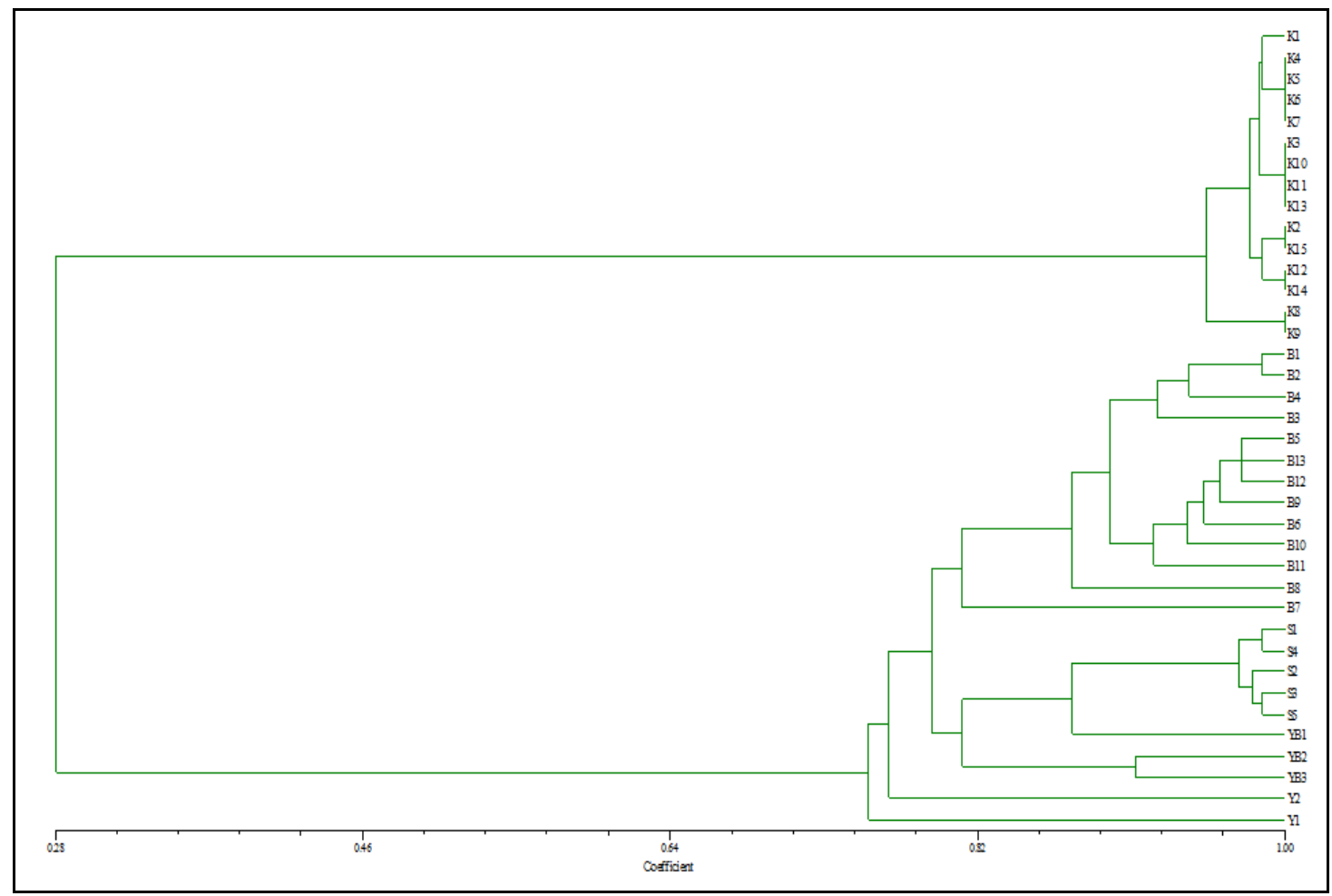

Figure 3. Dendrogram showing genetic relationships among value of ISSR markers for mulberry genotypes (K: Black mulberry, B: White mulberry, S: Weeping (Pendulous) mulberry, $Y$ : Everbearing mulberry (long season harvesting), YB: Wild mulberry)

While the small main group in the dendrogram only consists of black mulberry genotypes, the major groups include white mulberry, weeping mulberry, everbearing and wild white mulberry genotypes. However, in the major group, mulberry genotypes belonging to different species constituted their subgroups. The level of polymorphism between black mulberry genotypes was very low. While no polymorphism was observed in the great majority of 15 genotypes of black mulberry genotypes, the lowest similarity level in this species is $94 \%$ in dendrogram. The lowest level of similarity within the other species were $96 \%$ in the weeping mulberry, $80 \%$ in the white and wild white mulberry and $75 \%$ in the everbearing mulberry genotypes.

The wild and everbearing white mulberry genotypes were most likely grown from seed. Therefore, these mulberry genotypes showed the least similarities and the greatest polymorphism was obtained from these genotypes. Although $100 \%$ similarities were not obtained within the group, polymorphism was low in weeping mulberry genotypes. Significant differences were determined within the group in white mulberry genotypes, and $100 \%$ similarities were not observed. The majority of black mulberry genotypes were similar to each other, most of which can be caused by vegetative propagation from 
a single source by grafting, cutting or dipping. As a matter of fact, previous studies indicate that seeds of black mulberry genotypes hardly germinate without any pretreatment (Güneş and Çekiç, 2004). In addition, this example is true because the sample area is narrow and there is only one or two black mulberry trees in producer gardens. The results of this study will then shed light on the work to be done for vegetative propagation in this area. Also, the principle component analysis generally put the genotypes into different clusters as parallel to morphological differences of the mulberry species (Fig. 4).
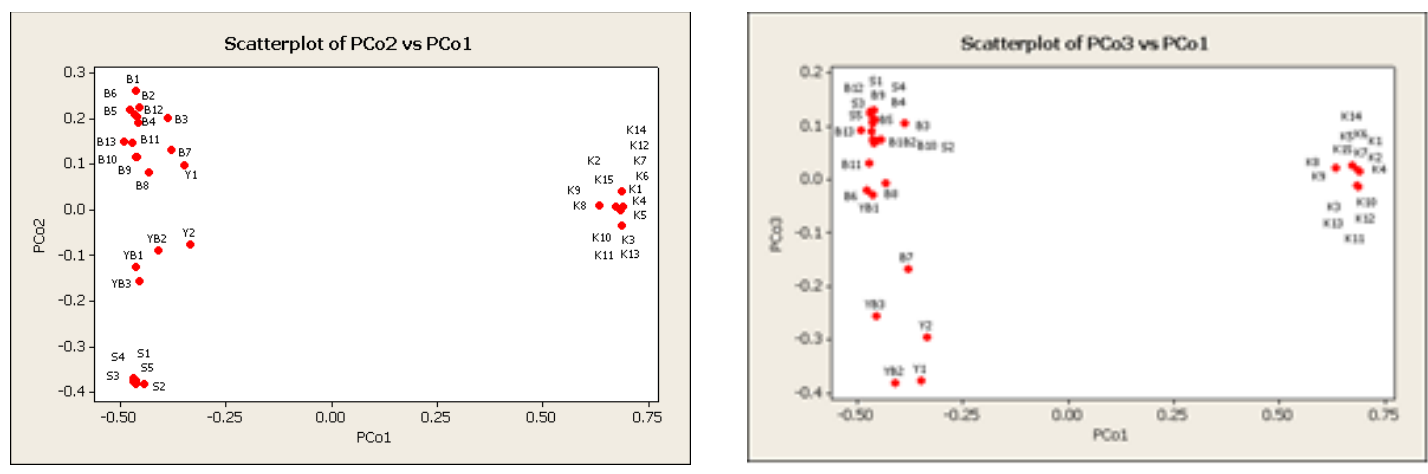

Figure 4. The principle component analysis of mulberry genotypes according to 15 ISSR primers

\section{Conclusion}

The results of the study mean that molecular tools are more reliable than the phenotypic observations as the well-known fact. Screening of the 38 genotypes of different mulberry species revealed that banding profiles obtained with fifteen ISSR primers were enough to distinguish the diversity between species or within the species. The results indicated that the ISSR technique is effective to develop genotype-specific banding patterns valuable for genotype identification. Since ISSR-PCR technique does not require previous DNA sequence information and uses very small quantity of DNA, it is considered as one of the most widely used techniques for genotype identification and genetic diversity studies. These results mean that molecular tools are more reliable than the phenotypic observations for evaluating variations and monitoring genetic stability.

The wide variation in genetic distance among the different mulberry species revealed by ISSR techniques reflected a high level of polymorphism at the DNA level. The genetic similarity of different mulberry species is low as indicated ISSR analyses. The variability in black mulberry genotypes within the species has been characterized as quite low. We can conclude that the saplings of black mulberry were mostly obtained by budding or cutting from local sources. There are some flows in other mulberry species from outside the province as we can see wide variation within the species.

\section{REFERENCES}

[1] Anonymous (2006): TÜBITAK - The Databases of Turkey Taxonomic Species. http://biow.tubitak.gov.tr/present/taxonForm1.jsp?taxon=4480.

[2] Anonymous (2009): Mulberry. - http://www.crfg.org/pubs/ff/mulberry.html. 
[3] Awasthi, A. K., Nagaraja, G. M., Naik, G. V., Kanginakudru, S., Than Gavelu, K., Nagaraju, J. (2004): Genetic diversity and relationships in mulberry (genus Morus) as revealed by RAPD and ISSR marker assays. - BMC Genetics 5: 1. http://www.biomedcentral.com/1471-2156/5/1.

[4] Cekic, C., Battey, N. H., Wilkinson, M. J. (2001): The potential of ISSR-PCR primer pair combinations for genetic linkage analysis using the seasonal flowering locus in Fragaria vesca as a model. - Theoretical and Applied Genetics 103(4): 540-546.

[5] Charters, Y. M., Robertson, A., Wilkinson, M. J., Ramsay, G. (1996): PCR analysis of oilseed rape cultivars (Brassica napus L ssp oleifera) using 5'-anchored simple sequence repeat (SSR) primers. - Theoretical and Applied Genetics 92(3-4): 442-447.

[6] Datta, R. K. (2002): Mulberry cultivation and utilization in India. Mulberry for animal production. - FAO Animal Production and Health Paper 147: 45-62.

[7] Doyle, J. J., Doyle, J. L. (1987): A rapid DNA isolation procedure for small quantities of fresh leaf tissue. - Phytochemical Bulletin 19: 11-15.

[8] Ercisli, S. (2004): A short review of the fruit germplasm resources of Turkey. - Gen. Res. Crop Evaluation 51: 419-435.

[9] Ercisli, S., Orhan, E. (2007): Chemical composition of white (Morus alba), red (Morus rubra) and black (Morus nigra) mulberry fruits. - Food Chem. 103: 1380-1384.

[10] Erdoğan, Ü., Prrlak, L. (2005): Utilization and production of mulberry (Morus spp.) in Turkey. - Alatarmm 4(2): 38-43.

[11] Güneş, M., Çekiç, Ç. (2004): The effects of pretreatments and dark-light conditions on the seed germination of different mulberry species. - Asian Journal of Chemistry 16: $1842-1848$.

[12] Özgen, M, Serçe, S., Kaya, C. (2009): Phytochemical and antioxidant properties of thocyanin-rich Morus nigra and Morus rubra fruits. - Sci. Hortic. 119: 275-279.

[13] Rafalski, J. A., Vogel, J. M., Morgante, M., Powell, W., Andre, C., Tingey, S. V. (1996): Generating New DNA Markers in Plants. - In: Birren, B., Lai, E. (eds.) Non-mammalian Genomic Analysis: A Practical Guide. Academic Press, New York.

[14] Rohlf, F. J. (1992): NTSYS-pc Numerical Taxonomy and Multivariate Analysis System Version 1.8. - Appl. Biostatistics, New York.

[15] Tutin, G. T. (1996): Morus L. - In: Tutin, G. T., Burges, N. A., Chater, A. O., Edmondson, J. R., Heywood, V. H., Moore, D. M., Valentine, D.H., Walters, S. M., Webb, D. A. (eds.) Flora Europaea, Vol. 1. Psilotaceae to Platanaceae. 2nd ed. Cambridge University Press, Australia.

[16] Vijayan, K., Srivastava, P. P., Awasthi, A. K. (2004): Analysis of phylogeneticrelationship among five mulberry (Morus) species using molecular markers. - Genome 47(3): 439-448. 